\title{
Niche partitioning in the Fiordland wrasse guild
}

\author{
Jean P. Davis, Stephen R. Wing* \\ Department of Marine Science, University of Otago, PO Box 56, Dunedin 9054, New Zealand
}

\begin{abstract}
Niche space is a useful indicator of trophic diversity in marine ecosystems. Here we describe the characteristics of realized niche space of 3 sympatric labrids (Notolabrus celidotus, Notolabrus fucicola, and Pseudolabrus miles) in Fiordland, New Zealand. We investigate physical niche through relationships between environmental parameters and patterns in abundance at a regional scale. Abundances of $P$. miles and $N$. fucicola were best associated with high salinity, wave-exposed areas $\left(\mathrm{r}^{2}=0.637,0.372\right.$ respectively) while $N$. celidotus was positively correlated with calm semi-estuarine conditions $\left(\mathrm{r}^{2}=0.452\right)$. Variation in biological habitat descriptors of wrasse abundance provided evidence for differences in the environmental correlates for abundance among species, though all were positively correlated with abundance of macroalgae (Ecklonia radiata). Stable isotope analysis identified individual variability in trophic position among species by revealing that $P$. miles fed at a significantly higher trophic level and had a higher percentage of macroalgae in their composition of basal organic matter than $N$. celidotus and N. fucicola. N. celidotus had a significantly higher dispersion of individual trophic levels and percentage macroalgae than $P$. miles and $N$. fucicola, indicating a broader trophic niche. Isotopic results were supported by prey choices identified in gut content analysis and qualitative observations of tooth morphology. In Fiordland, $N$. celidotus is a generalist species, successfully exploiting a range of resources along the gradient from inner to outer fjord habitat, while $P$. miles and $N$. fucicola are relatively specialized to wave-exposed coastal habitats. These methods provide a useful approach to the quantitative comparison of niche breadth among species.
\end{abstract}

KEY WORDS: Niche space - Stable isotopes - Trophic level · Food web - Fjord · Akaike's information criterion $\cdot$ DistLM

\section{INTRODUCTION}

The parameters of niche space offer a useful description of the functional roles of co-existing reef fish in subtidal ecosystems because the concept of niche is multidimensional, including abiotic as well as biotic influences on a fish's natural distribution (Hutchinson 1957, Tokeshi 1999). Niche space may then be characterized by measuring specific proxies of biological and physical niche. For example, physical niche space is often described for fishes using observations of abundance and distribution. Reef fish partition space in response to physiologically limiting variables such as salinity (Wellenreuther et al. 2008), wave exposure (Fulton \& Bellwood 2005) and light (McFar- land 1986) as well as biological variables such as prey distribution or habitat structure (Polovina 1996, Pérez-Matus \& Shima 2010). Therefore, characterizing niche space requires a multivariate approach.

Diet is a useful proxy for the biological niche space of fishes (Hajisamae et al. 2004, Azzurro et al. 2007). Stable isotopic signatures are valuable as they give an integrated description of diet over a longer timescale than gut contents (Pinnegar \& Polunin 2000). Stable isotopes are increasingly accepted as a fundamental technique for characterizing ecological niche space in a standardized way (Newsome et al. 2007). Though individual niche variation is often overlooked, it may often contribute to the overall niche breadth of fish populations (Bolnick et al. 2003). For 
example, isotopic analysis of 19 fish species in a large North American lake revealed unexpectedly high differences in individual feeding behavior in addition to those predicted at the community level (Fry et al. 1999). Long-term variation in diet among individuals is important to consider when characterizing the niche breadth of a population.

In the present study, we investigated physical and biological proxies for niche space among 3 species of wrasse (Family Labridae) commonly observed in subtidal rocky reef habitats across Fiordland, New Zealand (Roberts et al. 2005). The objective of the present study was to identify the realized niche space of 3 wrasses common to Fiordland using proxies for biological and physical niche. Realized niche space refers to the actual space which a species is best adapted to and which it occupies because of competition and predation. Physical niche was described by modeling patterns of Fiordland-wide wrasse abundance against physical and biological variables using an information theoretic approach. Biological niche was characterized using gut contents analysis paired with analysis of $\delta^{13} \mathrm{C}$ and $\delta^{15} \mathrm{~N}$ with a mass balance model, providing estimates of individual variability in trophic level as well as in composition of basal organic matter use. Combining the physical limitations of abundance among habitats with resource use within these habitats created a description of realized niche.

\section{MATERIALS AND METHODS}

\section{Study site}

Fiordland, a series of 14 fjords on the southwest coast of the South Island, represents an area unique within New Zealand because of its extreme glacial topography and resulting biological and physical gradients. These sharp environmental gradients affect the community structure of Fiordland's subtidal habitats, creating a useful study system for characterizing niche space. With shallow sills at the ocean entrance and deep sheltered basins up to $450 \mathrm{~m}$ below sea level surrounded by steep mountain peaks $(\sim 1700 \mathrm{~m})$, fjords experience strong variability in solar irradiance due to topographic shading (Wing et al. 2007) and a change from high levels of mixing at the waveexposed open coast to a relatively calm inner fjord environment (Wing et al. 2004). These physical gradients in turn affect macroalgal density along the fjord axis (Wing et al. 2007), which is a key source of habitat complexity for reef fish and a major source of or- ganic matter to the subtidal food web (Anderson 1994). Salinity also changes substantially over the length of the fjord as a result of heavy rainfall and riverine input. Low inner fjord salinity levels have been associated with altered subtidal food web structure (Rutger \& Wing 2006, McLeod \& Wing 2008) that limits prey availability for wrasses (McLeod et al. 2010). Consequently, outer fjord habitats are highly productive, using wave energy to support benthic production in Ecklonia radiata kelp forest-dominated subtidal communities, while the calm, semi-estuarine, low light environment in the inner fjord supports invertebrate and black coral Antipathes fiordensis dominated ecosystems where large kelps are less abundant and macroalgae are largely estuarine species growing in the low salinity layer (Wing et al. 2007, McLeod \& Wing 2008).

\section{Study species}

Spotties Notolabrus celidotus are the smallest of the 3 wrasses and are protogynous hermaphrodites, reaching sexual maturity at around $1 \mathrm{yr}$ old and 10 to $15 \mathrm{~cm}$ in length with a maximum size of $\sim 22 \mathrm{~cm}$ (Jones 1980). Scarlet wrasse Pseudolabrus miles are similarly hermaphroditic but larger, reaching a size of $\sim 32.5 \mathrm{~cm}$ in length and maturing at around $4 \mathrm{yr}$ (Francis 1988). Banded wrasse Notolabrus fucicola are the largest of the 3 species $(\sim 40 \mathrm{~cm})$ and are secondary gonochorists, reaching maturity at $\sim 20 \mathrm{~cm}$ (Denny \& Schiel 2002). Labrids are one of the most abundant and conspicuous reef fish families within New Zealand (Denny 2005) and have been observed to feed primarily on sea urchins Evechinus chloroticus, mollusks and crustaceans (Russell 1983, Jones 1984b, Denny \& Schiel 2001). Sea urchins are regulators of algal density (Choat \& Schiel 1982) and exist over a range of environments (Wing et al. 2003), which suggests that via predation wrasses may help maintain algal communities valuable to other species for shelter and food (Schiel \& Hickford 2001). Additionally, predation by wrasses on mussels in southern New Zealand likely provides significant top down control in structuring ecological communities on shallow temperate reefs (Rilov \& Schiel 2006, Wing \& Leichter 2011).

\section{Physical variables}

The physical variables of surface salinity, significant wave height, and solar irradiance were cho- 
sen to describe patterns in wrasse abundance and distribution based on predicted physiological limitations and related biological gradients (Witman \& Grange 1998, Wing et al. 2007, McLeod \& Wing 2008). These variables were characterized previously as part of a Fiordland-wide monitoring project (Wing et al. 2004). Detailed methods can be found in Wing et al. (2007).

Surface salinity was recorded at $2 \mathrm{~m}$ depth using replicate CTD surveys over $100 \mathrm{~m}$ intervals with a Seabird SBE 19 CTD during 1998, 1999, 2002, 2003, 2004 and 2005 (Wing et al. 2004). Surface salinity values represent average salinity in the upper $2 \mathrm{~m}$ of the water column. Significant wave height was determined using a simulating waves near shore (SWaN) (Delft University of Technology) model that created a regional wave exposure map based on physical processes affecting wave formation as well as $20 \mathrm{yr}$ of hindcasted data on wind and wave parameters (Wing et al. 2007). Regions were broken up into $10^{\circ}$ bins and combined into a weighted mean of significant wave height. Fiordland wide solar irradiance data was modeled at $50 \mathrm{~m}$ intervals using atmospheric turbidity values in the GRASS GIS package (Wing et al. 2007). Values took into account local topography and the effects of shading.

\section{Biological variables}

Biological variables were chosen to describe patterns in wrasse abundance that might reflect diet or habitat preference. Densities of kelp Ecklonia radiata and sea urchins Evechinus chloroticus were collected during February 2010 using 6 to 8 paired $2 \mathrm{~m}^{2}$ quadrats at 5, 10 and $15 \mathrm{~m}$ depths throughout Fiordland (Fig. 1). Site average abundances were determined by averaging over quadrat pairs and depth strata.

Photoquadrats of rock wall communities from the same sites and sample period provided data on the abundance of encrusting sessile invertebrates. Ten $0.17 \mathrm{~m}^{2}$ photoquadrats were taken along rock walls at stratified depths of $0,2.5,5,10,15$, and $20 \mathrm{~m}$ at each site. Photographs were then analyzed for abundances of brachiopods (Liothyrella noezelandea, Terebratella spp., Notosaria nigricans), mussels (Mytilus edulis galloprovincialis, Perna canaliculus) and barnacles. Species were summed by taxonomic group and averaged over depth and quadrat as the abundance per $0.17 \mathrm{~m}^{2}$ at each site. Barnacle abundance was calculated as the mean percent occurrence

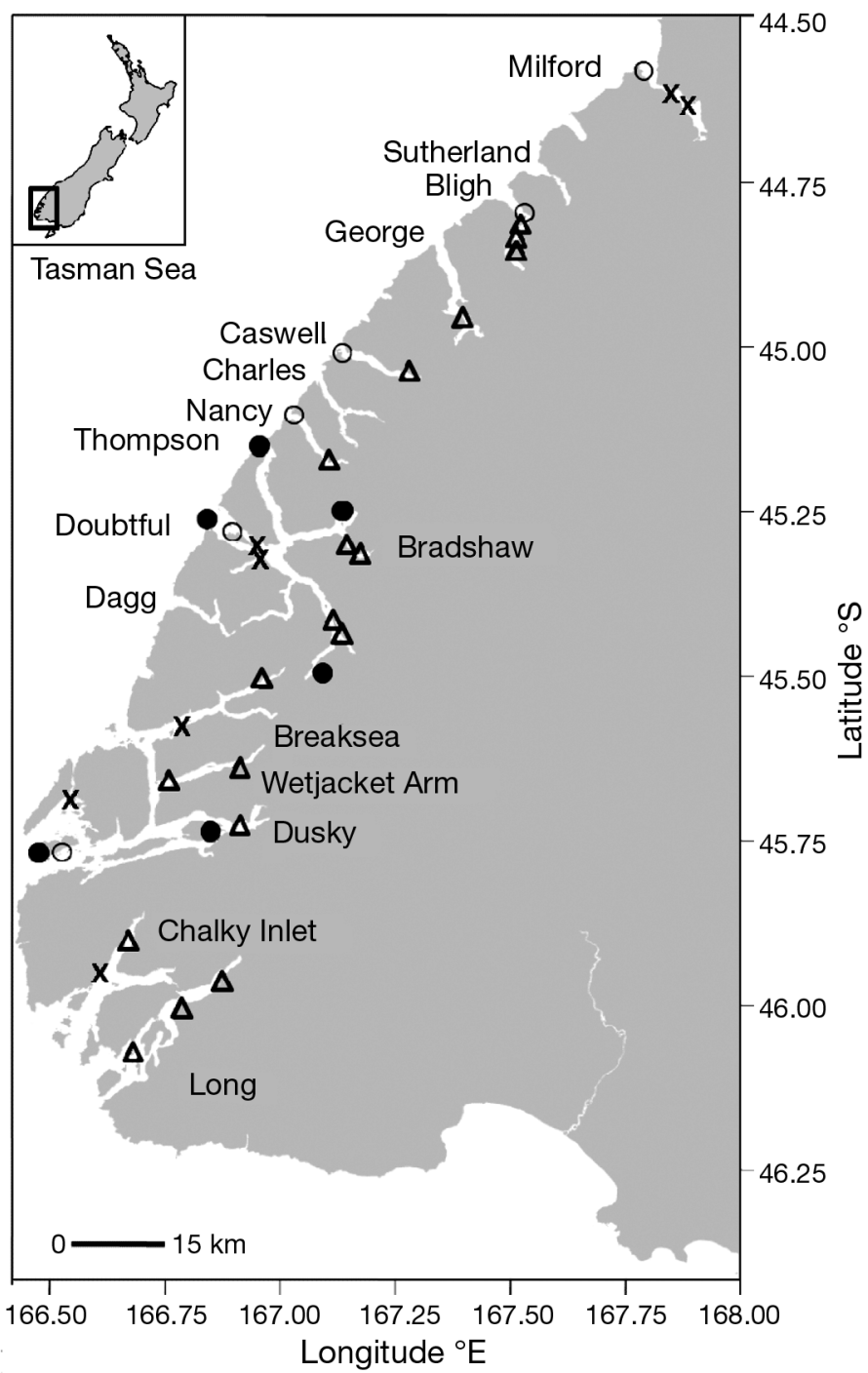

Fig. 1. Survey sites in Fiordland, New Zealand, where fish, invertebrate and kelp Ecklonia radiata were monitored in 2006, 2007 and 2010. ( $\Delta$ ) inner fjord, (x) mid fjord, (O) outer fjord, (๑) Notolabrus fucicola, Pseudolabrus miles and N. celidotus collection sites (2009 and 2010)

among multiple samples per site as it was not possible to gain accurate counts of individual abundance via photographs.

\section{Fish survey methods}

Survey sites for wrasse abundance were previously classified into habitat types (inner, mid and outer fjord habitats) based on Ward's hierarchical analysis by combining 3 biological indicators of habitat into a GIS framework (Wing \& Jack 2010). The 3 biological indicators of habitat were mean sea urchin test dia- 
meter, which is an estimate of sea urchin size structure and nutritional history, kelp blade morphology, which indicates differences in primary production among sites, and reef fish community structure, whereby fish species are classified into 2 distinct inner and outer fjord guilds by abundance (Wing \& Jack 2010).

Abundance data were drawn from monitoring surveys across the Fiordland Marine Area (FMA) during 2006, 2007 and 2010 (Wing 2006, Wing \& Jack 2010). Wrasse abundances were obtained from replicate depth-stratified $(5,10$ and $15 \mathrm{~m}) 50 \mathrm{~m}$ (length) $\times 5 \mathrm{~m}$ (width) $\times 2.5 \mathrm{~m}$ (height) band-transect surveys at 31 sites (survey area: $250 \mathrm{~m}^{2}$, volume: $625 \mathrm{~m}^{3}$ ) (Fig. 1). Underwater visual census (UVC) techniques that were compatible with those in previous Fiordlandwide fish surveys (Wing et al. 2004) were used.

\section{Abundance among habitats}

To investigate patterns in abundance, the abundances (fish $250 \mathrm{~m}^{-2}$ ) of each wrasse species were pooled over depth strata $(5,10$ and $15 \mathrm{~m}$ replicates) for all survey years (no significant difference in abundance was found among years for all species) and tested for differences among 3 habitat types along the fjord axis (inner, mid and outer fjord). A singlefactor permutational multivariate analysis of variance (PERMANOVA) (Anderson 2001) performed in the PERMANOVA + add-on to PRIMER6, tested the fixed factor 'Habitat type' (3 levels) and was applied to square-root transformed abundance data for each wrasse species in a Bray-Curtis similarity matrix with a maximum of 9999 permutations. The a posteriori pair-wise test was applied to significant factors. A permutational analysis of multivariate dispersions (PERMDISP) was applied to test the homogeneity of multivariate dispersion (Anderson et al. 2008). A principle coordinate analysis ordination ( $\mathrm{PCO}$ ) plot was used to visualize abundance of individual fish in relation to overall wrasse community structure.

\section{Information theoretic analysis}

An information theoretic approach was used to model the relationship between wrasse abundance and environmental predictor variables. The correlations from physical and biological models are not used to infer causality but represent a framework to consider the likely influence of multiple interrelated contributing mechanisms. In order to rank the com- peting models, data were analyzed using a distance based multivariate analysis for a linear model (DistLM) using corrected Akaike's information criterion $\left(\mathrm{AIC}_{\mathrm{c}}\right)$ selection criteria (McArdle \& Anderson 2001), an application of PERMANOVA+. DistLM was applied to square-root transformed wrasse abundance in a Euclidean distance similarity matrix with a maximum of 9999 permutations. Square root transformed abundances of Notolabrus celidotus, N. fucicola and Pseudolabrus miles were compared with square-root transformed physical (surface salinity, significant wave height and solar irradiance) and biological (abundance of kelp, sea urchins, barnacles, brachiopods and mussels) predictor variables from all 31 study sites. Both 'Best' and 'All specified' selections were applied to an $\mathrm{AIC}_{\mathrm{c}}$ criterion. The $\mathrm{AIC}_{\mathrm{C}}$ criterion is used when the ratio of samples $(N)$ to predictor $(v)$ variables is small $(N / v<40)$ as in this study (Burnham \& Anderson 1998). The equation for $\mathrm{AIC}_{\mathrm{C}}$ is (Burnham \& Anderson 1998):

$$
\mathrm{AIC}_{\mathrm{c}}=\mathrm{AIC}+\frac{[2 K(K+1)]}{[n-K-1]}
$$

where AIC is the uncorrected Akaike's information criterion, $K$ is the number of estimated parameters and $n$ is the sample size. Results are presented as suggested by Burnham \& Anderson et al. (1998). To further assess the importance of each model (i), the change in $\operatorname{AIC}_{\mathrm{c}}\left(\Delta_{i}\right)$ was calculated by subtracting each model's $\mathrm{AIC}_{\mathrm{c}}$ from the model with the lowest $\mathrm{AIC}_{\mathrm{c}}$ (best fit model). AIC $\mathrm{C}_{\mathrm{c}}$ weights $\left(w_{i}\right)$ were calculated to give a proportional weighting for each model. The model with the highest $w_{i}$ is the best fit model:

$$
W_{i}=\frac{-\exp \left(-0.5 \Delta_{i}\right)}{\sum-\exp \left(-0.5 \Delta_{i}\right)}
$$

The summed weights of each predictor variable were calculated by summing the $w_{i}$ for each model containing that factor to look at the overall importance of individual factors.

\section{Sample collection for diet analysis}

Wrasses were collected from 6 sites ( 3 inner fjord and 3 outer fjord) using both hook and line and pole spear during the austral summer of 2009 and 2010 (Fig. 1, Table 1). Samples consisted of 4 to 10 individuals of each species per site from Doubtful Sound, the Thompson-Bradshaw complex and Dusky Sound. Only Notolabrus celidotus were collected at inner fjord sites due to low abundance of Pseudolabrus miles and N. fucicola. 
Table 1. Notolabrus fucicola, Notolabrus celidotus and Pseudolabrus miles. Number of samples of 3 wrasse species for stable isotope and stomach content analysis and the size range of fish collected at 3 outer fjord and 3 inner fjord sites in Fiordland, New Zealand, between November 2009 and February 2010. SL: standard length; na: not applicable

\begin{tabular}{|c|c|c|c|c|c|c|}
\hline \multirow{2}{*}{ Species/site } & \multicolumn{3}{|c|}{ - Outer fjord- } & \multirow[b]{2}{*}{$\begin{array}{c}\text { No. of } \\
\text { gut analysis } \\
\text { samples }\end{array}$} & \multirow{2}{*}{$\begin{array}{l}\text { Inner fjord } \\
\text { No. of } \\
\text { stable isotope } \\
\text { samples }\end{array}$} & \multirow[b]{2}{*}{$\begin{array}{l}\text { Size range } \\
(\mathrm{mm} \text { SL) }\end{array}$} \\
\hline & $\begin{array}{c}\text { No. of } \\
\text { gut analysis } \\
\text { samples }\end{array}$ & $\begin{array}{c}\text { No. of } \\
\text { stable isotope } \\
\text { samples }\end{array}$ & $\begin{array}{l}\text { Size range } \\
(\mathrm{mm} \mathrm{SL})\end{array}$ & & & \\
\hline \multicolumn{7}{|c|}{ Notolabrus fucicola } \\
\hline Doubtful & 5 & 5 & $145-272$ & 0 & 0 & \\
\hline Dusky & 10 & 11 & $127-361$ & 0 & 2 & $340-360$ \\
\hline Thompson & 8 & 10 & $145-310$ & na & na & na \\
\hline Bradshaw & na & na & na & 0 & 0 & \\
\hline \multicolumn{7}{|c|}{ Pseudolabrus miles } \\
\hline Doubtful & 4 & 4 & $145-250$ & 0 & 0 & \\
\hline Dusky & 13 & 15 & $122-259$ & 0 & 3 & $220-315$ \\
\hline Thompson & 7 & 8 & $136-215$ & na & na & na \\
\hline Bradshaw & na & na & na & 0 & 0 & \\
\hline \multicolumn{7}{|c|}{ Notolabrus celidotus } \\
\hline Doubtful & 11 & 10 & $155-241$ & 6 & 8 & 108-183 \\
\hline Dusky & 10 & 14 & $95-200$ & 5 & 10 & $122-225$ \\
\hline Thompson & 10 & 10 & $110-137$ & na & na & na \\
\hline Bradshaw & na & na & na & 11 & 14 & $120-190$ \\
\hline
\end{tabular}

\section{Gut contents analysis}

All fish were weighed to the nearest $0.1 \mathrm{~g}$ and measured to the nearest $1 \mathrm{~mm}$ in standard length. Whole stomachs were removed, preserved in $10 \%$ formalin, degassed and transferred to $70 \%$ isopropyl alcohol (IPA). Content of each stomach was categorized into 18 general trophic groups and weighed to the nearest $0.01 \mathrm{~g}$. A modified index of relative importance (IRI) was used to present the relative importance of prey categories in the diet of each species based on the percent weight $(\% W)$ and percent frequency $(\% F)$ of occurrence of each category (Pinkas et al. 1971):

$$
\mathrm{IRI}=\% W \times \% F
$$

To test overlap in wrasse diet the Morisita-Horn Index of niche overlap was applied to all diet categories, using the transformation 'presence absence' for all prey items (Horn 1966):

$$
C_{\mathrm{MH}}=2\left[\Sigma\left(n_{\mathrm{A} i} \times n_{\mathrm{B} i}\right)\right] /\left[\left(D_{\mathrm{A}}+D_{\mathrm{B}}\right) \times N_{\mathrm{A}} \times N_{\mathrm{B}}\right]
$$

where $N_{\mathrm{A}}$ is the total number of individuals of all species collected at Site A, $N_{\mathrm{B}}$ the total number of all species collected at Site $\mathrm{B}, n_{\mathrm{A} i}$ is the number of individuals of species $i$ from Site $\mathrm{A}, n_{\mathrm{B} i}$ is the number of individuals of species $i$ from Site $B, D_{\mathrm{A}}$ is Simpson's Diversity Index determined for Site $A$, and $D_{B}$ is Simpson's Diversity Index determined for Site B. The Morisita-Horn Index $\left(C_{\mathrm{MH}}\right)$ is a value of the percent overlap between diets that ranges between 0 (no overlap) and 1 (perfect overlap). Values greater than 0.6 , or $60 \%$, indicate significant overlap. For each site, Simpson's Diversity Index was determined as:

$$
\begin{aligned}
& D_{\mathrm{A}}=\Sigma\left(n_{\mathrm{A} i} / N_{\mathrm{A}}\right)^{2} \\
& D_{\mathrm{B}}=\Sigma\left(n_{\mathrm{B} i} / N_{\mathrm{B}}\right)^{2}
\end{aligned}
$$

\section{Stable isotope analysis}

A plug of muscle tissue was removed from the left dorsolateral side of each fish shortly after capture and oven dried at $\sim 60^{\circ} \mathrm{C}$. Samples were then ground to a fine powder using mortar and pestle. From each muscle sample a $1 \mathrm{mg}$ subsample was weighed and sealed in a tin capsule for stable isotope analysis of $\delta^{13} \mathrm{C}$ and $\delta^{15} \mathrm{~N}$. Samples were analyzed by Iso-trace NZ in the Department of Chemistry, University of Otago on a Europa Scientific 20-20 Update stable isotope mass spectrometer interfaced with a Carlo Erba NA1500 elemental analyzer in continuous flow mode (precision: $0.2 \%$ for $\delta^{13} \mathrm{C}, 0.3 \%$ for $\delta^{15} \mathrm{~N}$ ). Primary standards for analysis were calibrated to EDTA laboratory standard reference (Elemental Microanalysis) and standardized against international standards (IAEACH-6 for carbon, IAEAN1 and IAEAN2 for nitrogen). The primary standard for $\delta^{15} \mathrm{~N}$ was atmospheric air and for $\delta^{13} \mathrm{C}$ Peedee belemnite limestone. 
Table 2. Pair-wise permutational multivariate analysis of variance (PERMANOVA) and permutational analysis of multivariate dispersions (PERMDISP) test results indicating differences in wrasse abundance among 3 habitat types along the fjord axis. Significant differences in bold $(\mathrm{p}<0.05)$

\begin{tabular}{|c|c|c|c|c|c|c|c|}
\hline Species & Habitat types & $\mathrm{df}$ & $\begin{array}{c}\text { ERMAN } \\
t\end{array}$ & $\bar{p}$ & $\mathrm{df}$ & $\begin{array}{l}\text { PERMDISP } \\
t \quad\end{array}$ & $\mathrm{p}$ \\
\hline Notolabrus fucicola & $\begin{array}{l}\text { Inner, mid } \\
\text { Inner, outer } \\
\text { Mid, outer }\end{array}$ & $\begin{array}{l}1,54 \\
1,54 \\
1,30\end{array}$ & $\begin{array}{l}4.3056 \\
8.0161 \\
3.0600\end{array}$ & $\begin{array}{l}0.0001 \\
0.0001 \\
0.0041\end{array}$ & $\begin{array}{l}1,69 \\
1,69 \\
1,69\end{array}$ & $\begin{array}{l}0.8261 \\
0.1061 \\
0.7146\end{array}$ & $\begin{array}{l}0.5811 \\
0.9374 \\
0.5092\end{array}$ \\
\hline Pseudolabrus miles & $\begin{array}{l}\text { Inner, mid } \\
\text { Inner, outer } \\
\text { Mid, outer }\end{array}$ & $\begin{array}{l}1,54 \\
1,54 \\
1,30\end{array}$ & $\begin{array}{l}5.8605 \\
6.0162 \\
0.5834\end{array}$ & $\begin{array}{l}\mathbf{0 . 0 0 0 1} \\
\mathbf{0 . 0 0 0 1} \\
0.5649\end{array}$ & $\begin{array}{l}1,69 \\
1,69 \\
1,69\end{array}$ & $\begin{array}{l}7.3953 \\
7.4198 \\
0.1230\end{array}$ & $\begin{array}{l}\mathbf{0 . 0 0 0 1} \\
\mathbf{0 . 0 0 0 1} \\
0.9220\end{array}$ \\
\hline Notolabrus celidotus & $\begin{array}{l}\text { Inner, mid } \\
\text { Inner, outer } \\
\text { Mid, outer }\end{array}$ & $\begin{array}{l}1,54 \\
1,54 \\
1,30\end{array}$ & $\begin{array}{l}4.7051 \\
6.1873 \\
1.0727\end{array}$ & $\begin{array}{l}\mathbf{0 . 0 0 0 1} \\
\mathbf{0 . 0 0 0 1} \\
0.2859\end{array}$ & $\begin{array}{l}1,69 \\
1,69 \\
1,69\end{array}$ & $\begin{array}{l}2.5925 \\
2.3040 \\
0.1504\end{array}$ & $\begin{array}{l}\mathbf{0 . 0 2 5 1} \\
\mathbf{0 . 0 3 0 0} \\
0.9076\end{array}$ \\
\hline
\end{tabular}

\section{Trophic position}

$\delta^{13} \mathrm{C}$ and $\delta^{15} \mathrm{~N}$ values for all 3 species of wrasse were considered relative to $\delta^{13} \mathrm{C}$ and $\delta^{15} \mathrm{~N}$ of primary basal organic matter sources of suspended particulate organic matter $\left(\mathrm{SPOM}_{;} \delta^{13} \mathrm{C}=-23.5, \delta^{15} \mathrm{~N}=5.0\right)$ and macroalgae (Ecklonia radiata; $\delta^{13} \mathrm{C}=-18.0$, $\delta^{15} \mathrm{~N}=4.7$ ) in the Fiordland marine system (Wing et al. 2008). Though Doubtful Sound, Fiordland, supports multiple organic matter source pools (McLeod \& Wing 2007, McLeod et al. 2010) we only addressed SPOM and macroalgae as we did not consider the others useful for characterizing Fiordland-wide niche breadth among wrasses. First, a 2-source mass balance model IsoError (Phillips \& Gregg 2001) was run based on $\delta^{13} \mathrm{C}$ with a trophic discrimination factor of +0.4 and a factor of +2.3 for $\delta^{15} \mathrm{~N}$ (as is suggested for aquatic organisms by McCutchan et al. 2003, McLeod 2007) applied to an estimate of trophic level. Then the $\delta^{15} \mathrm{~N}_{\text {base }}$ value of the estimated mixture of basal organic matter sources was used as a base value from which to estimate trophic level. Individual trophic level was calculated by dividing the difference between $\delta^{15} \mathrm{~N}_{\text {base }}$ and the observed $\delta^{15} \mathrm{~N}$ of the individual by the trophic discrimination factor for $\delta^{15} \mathrm{~N}(+2.3)$. The estimate was then applied to the 2 source mass balance model using $\delta^{13} \mathrm{C}$, and iterations of these 2 models were run until a stable solution for the mixture of basal organic matter sources and for trophic level was reached for each individual. The resulting data provided an estimate of the trophic position for each individual sampled for the 3 species. From these data, estimates of both the mean and the dispersion of individual trophic positions were used to compare species. This metric provided a basis for understanding individual variability in trophic position and composition of basal organic matter.

From these data we could then determine how much individual variability in trophic position contributes to niche breadth. A 2-factor PERMANOVA design with the fixed factors 'Species' (3 levels) and 'Fjord' (3 levels) was applied to a Euclidean distance resemblance matrix of the raw values of estimated trophic level and percentage macroalgae in the diet for each fish sampled. Pair-wise tests indicated specific differences among species and fjords. A PERMDISP of the same design tested for differences in dispersion among species, which acts as a proxy for niche breadth.

\section{Morphology}

Dentary structure was observed from a single sample of each of the 3 wrasse species. Muscle and tissue was removed from jaws by boiling and dissection followed by soaking in a light bleach solution. Photographs were taken to scale using a video camera mounted to a dissecting microscope. Differences in morphology were evaluated qualitatively.

Table 3. Notolabrus fucicola, Notolabrus celidotus and Pseudolabrus miles. Mean $( \pm 1 \mathrm{SE})$ abundance (fish $250 \mathrm{~m}^{-2}$ ) of 3 wrasse species at each habitat type along the fjord axis

\begin{tabular}{|lccrr|}
\hline $\begin{array}{l}\text { Habitat } \\
\text { type }\end{array}$ & $\begin{array}{c}\text { Number } \\
\text { of sites }\end{array}$ & $\begin{array}{c}\text { Notolabrus } \\
\text { fucicola }\end{array}$ & $\begin{array}{c}\text { Pseudolabrus } \\
\text { miles }\end{array}$ & \multicolumn{1}{c|}{$\begin{array}{c}\text { Notolabrus } \\
\text { celidotus }\end{array}$} \\
\hline Inner & 18 & $0.523 \pm 0.601$ & $3.893 \pm 1.854$ & $17.407 \pm 6.117$ \\
Mid & 7 & $1.662 \pm 1.219$ & $18.098 \pm 4.514$ & $4.752 \pm 7.042$ \\
Outer & 6 & $3.817 \pm 2.594$ & $22.138 \pm 7.699$ & $2.927 \pm 3.121$ \\
\hline
\end{tabular}




\section{RESULTS}

\section{Abundance among habitats}

All 3 species of wrasse differed significantly in abundance among habitat types along the fjord axis (Notolabrus fucicola: pseudo- $F_{2,71}=33.594, \mathrm{p}<0.001$; $N$. celidotus: pseudo- $F_{2,105}=21.405, \mathrm{p}<0.001 ;$ Pseudolabrus miles: pseudo- $\left.F_{2,105}=34.235, \mathrm{p}<0.001\right)$. Pair-wise tests indicated that $P$. miles was signifi-
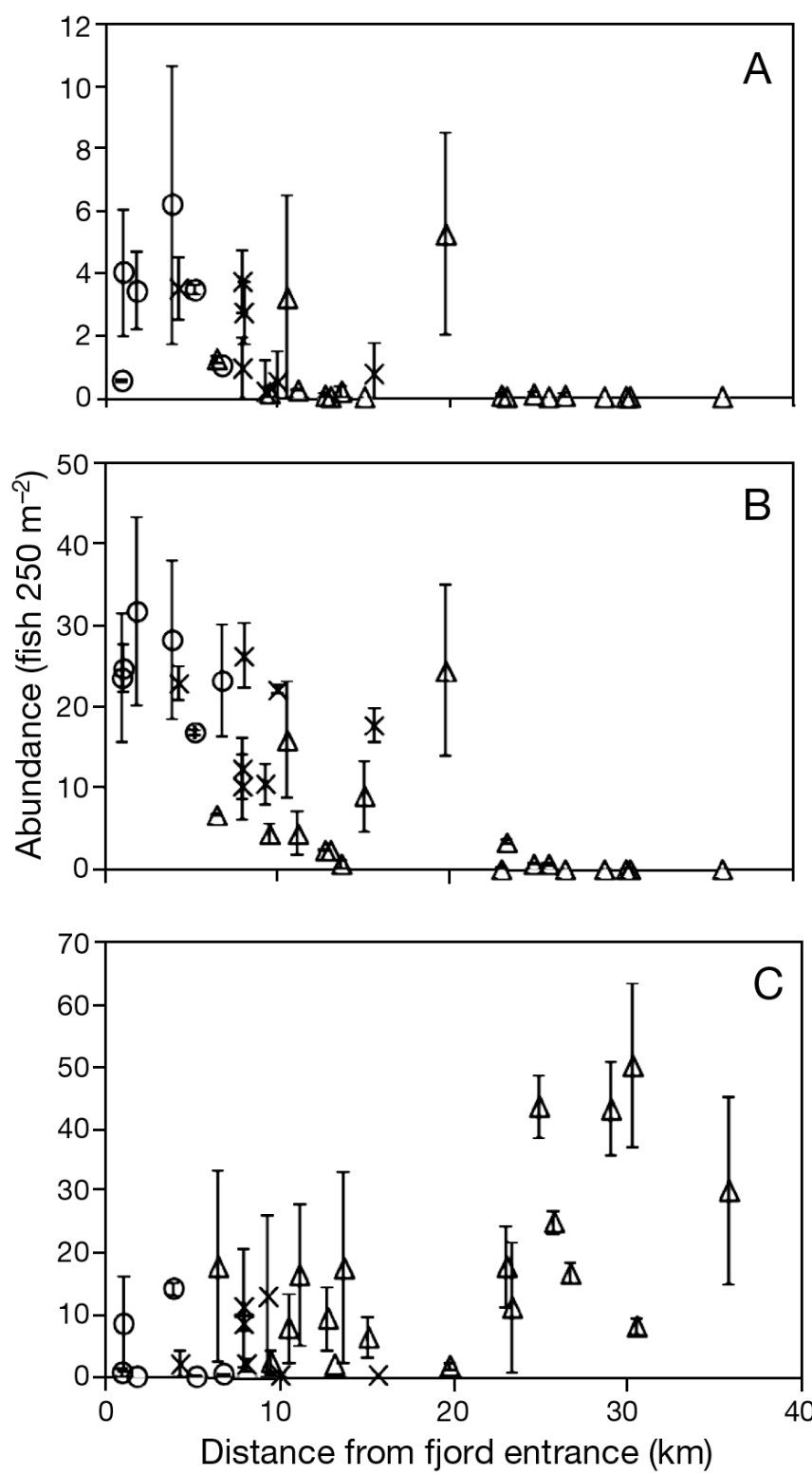

Fig. 2. Notolabrus fucicola, Notolabrus celidotus, and Pseudolabrus miles. Mean ( $\pm 1 \mathrm{SE}$ ) abundance (fish $250 \mathrm{~m}^{-2}$ ) of (A) N. fucicola, (B) P. miles and (C) N. celidotus as a function of distance from the entrance of the fjord for 31 Fiordland visual survey sites averaged over the years 2006, 2007 and 2010. $(\Delta)$ Inner fjord, $(\times)$ mid fjord, (O) outer fjord cantly more abundant at mid and outer fjord habitats while $N$. celidotus was more abundant at inner fjord habitats (Tables $2 \& 3$, Figs. $2 \& 3$ ). N. fucicola was significantly more abundant in outer fjord habitats. There were no significant differences in dispersion of abundances among habitats for $N$. fucicola; however, $N$. celidotus $\left(F_{2,69}=4.5662, \mathrm{p}<0.05\right)$ and $P$. miles $\left(F_{2,69}=51.197, \mathrm{p}<0.001\right)$ both had significant differences in dispersion at inner versus mid and inner versus outer fjord habitats (Table 2).

\section{Information theoretic analysis - physical modeling}

Abundances of all 3 wrasse species were most closely associated with the model 'Abundance = Surfsal $+\mathrm{H}_{\text {sig }}$ ' (Table 4). Abundance of Pseudolabrus miles was most successfully described by this model $\left(\mathrm{r}^{2}=0.637\right)$. However, abundances of Notolabrus celidotus and $N$. fucicola were poorly described $\left(\mathrm{r}^{2}=0.452\right.$ and 0.372 , respectively) in comparison. Summed weights indicated surface salinity as the best predictor variable for abundances of $N$. fucicola while significant wave height was slightly better associated with abundances of $P$. miles and $N$. celidotus (Table 5).

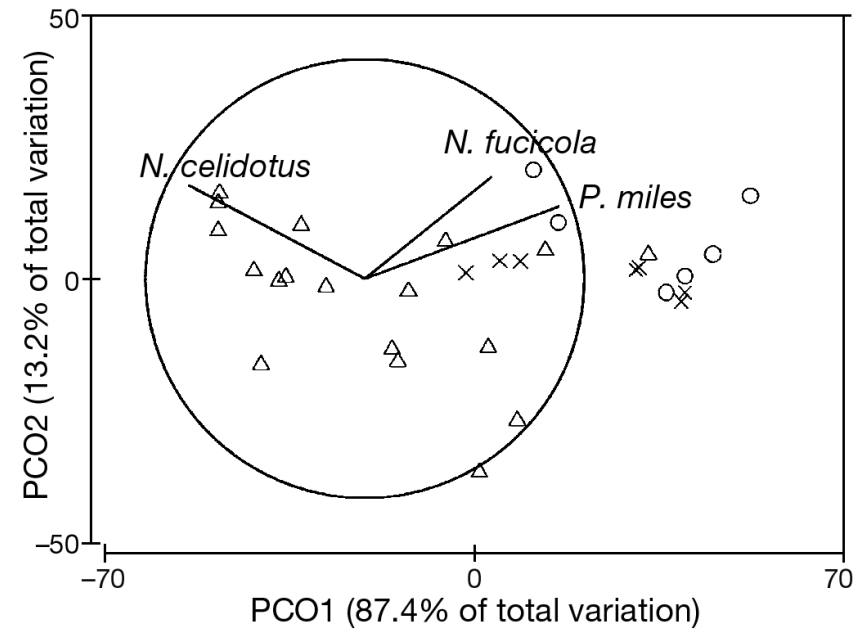

Fig. 3. Notolabrus fucicola, Notolabrus celidotus and Pseudolabrus miles. Principal component analysis ordination (PCO) plot of square-root transformed mean abundance (fish $250 \mathrm{~m}^{-2}$ ) of the 3 wrasse species surveyed at 31 sites throughout Fiordland, New Zealand, over the years 2006, 2007 and 2010. The length and direction of each vector indicate the strength and sign of the relationship between each fish species and the PCO axes. Vectors begin at the center of the circle and end at the coordinates of the correlations between species and each of the PCO axes. Symbols represent habitat types: $(\Delta)$ inner fjord, $(x)$ mid fjord, (O) outer fjord 
Table 4. Corrected Akaike's information criterion $\left(\mathrm{AIC}_{\mathrm{c}}\right.$ ) rank values for physical distance-based linear models (DistLM) as fitted to the abundance of 3 wrasse species. For all species $n=31$ survey sites. Only those models with cumulative total of Akaike's weights $>95 \%$ are presented. Surfsal: surface salinity; $\mathrm{H}_{\text {sig }}$ : significant wave height, Solarglob: solar global irradiance; $K$ : no. of model parameters; $\Delta_{i}$ : change in $\mathrm{AIC}_{c} ; W_{i}: \mathrm{AIC}_{\mathrm{c}}$ weight

\begin{tabular}{|c|c|c|c|c|c|c|c|}
\hline Species & Model & $\begin{array}{c}\text { Log } \\
\text { likelihood }\end{array}$ & $K$ & $\mathrm{AIC}_{\mathrm{c}}$ & $\Delta_{i}$ & $w_{i}$ & $r^{2}$ \\
\hline \multirow[t]{5}{*}{ Notolabrus fucicola } & Surfsal $+\mathrm{H}_{\text {sig }}$ & 2.519 & 4 & -21.460 & 0.000 & 0.372 & 0.372 \\
\hline & Solarglob $+\mathrm{H}_{\text {sig }}+$ Surfsal & 2.452 & 5 & -20.902 & 0.558 & 0.281 & 0.413 \\
\hline & Solarglob + Surfsal & 2.575 & 4 & -19.740 & 1.720 & 0.157 & 0.336 \\
\hline & $\mathrm{H}_{\text {sig }}$ & 2.698 & 3 & -18.375 & 3.085 & 0.080 & 0.249 \\
\hline & Surfsal & 2.707 & 3 & -18.104 & 3.356 & 0.069 & 0.242 \\
\hline \multirow[t]{2}{*}{ Pseudolabrus miles } & Surfsal $+\mathrm{H}_{\text {sig }}$ & 3.709 & 4 & 15.421 & 0.000 & 0.782 & 0.637 \\
\hline & Solarglob $+\mathrm{H}_{\text {sig }}+$ Surfsal & 3.709 & 5 & 18.068 & 2.647 & 0.208 & 0.637 \\
\hline \multirow[t]{4}{*}{ Notolabrus celidotus } & Surfsal $+\mathrm{H}_{\text {sig }}$ & 4.105 & 4 & 27.684 & 0.000 & 0.599 & 0.452 \\
\hline & Solarglob $+\mathrm{H}_{\mathrm{sig}}+$ Surfsal & 4.095 & 5 & 30.018 & 2.334 & 0.187 & 0.458 \\
\hline & $\mathrm{H}_{\text {sig }}$ & 4.279 & 3 & 30.622 & 2.938 & 0.138 & 0.348 \\
\hline & Solarglob $+\mathrm{H}_{\mathrm{sig}}$ & 4.256 & 4 & 32.378 & 4.694 & 0.057 & 0.363 \\
\hline
\end{tabular}

Table 5. Summed weights for each physical predictor variable based on the sum of the Akaike's information criterion weight $\left(w_{i}\right)$ for each model containing that factor. The highest ranking variables for each wrasse species are in bold. Surfsal: surface salinity; $\mathrm{H}_{\text {sig }}$ : significant wave height; Solarglob: solar global irradiance

\begin{tabular}{|lccc|}
\hline Factor & \multicolumn{3}{c|}{ Summed weight } \\
\cline { 2 - 4 } & $\begin{array}{c}\text { Notolabrus } \\
\text { fucicola }\end{array}$ & $\begin{array}{c}\text { Pseudolabrus } \\
\text { miles }\end{array}$ & $\begin{array}{c}\text { Notolabrus } \\
\text { celidotus }\end{array}$ \\
\hline Surfsal & $\mathbf{0 . 8 8 0 0}$ & $\mathbf{0 . 9 9 1 4}$ & 0.8045 \\
$\mathrm{H}_{\text {sig }}$ & 0.7697 & $\mathbf{0 . 9 9 9 1}$ & $\mathbf{0 . 9 8 1 2}$ \\
Solarglob & 0.4792 & 0.2107 & 0.2001 \\
\hline
\end{tabular}

\section{Information theoretic analysis - biological modeling}

The strongest model for describing abundance of Pseudolabrus miles and Notolabrus fucicola was 'Kelp + Sea urchins' (Table 6). The second best model for $P$. miles also included the abundance of brachiopods and held a similar factor weight. The best model for describing $N$. celidotus abundance was 'Kelp + Mussels'; however the explanatory power of the model was low $\left(\mathrm{r}^{2}=0.373\right)$, indicating that the biological models used were ultimately poor descriptors of abundance for this species. Abundance of kelp was the best individual predictor variable of wrasse abundance for all species (Table 7).

\section{Gut contents analysis}

The diet of all 3 wrasse species was dominated by invertebrate prey, mainly mollusks and crustaceans (Table 8). Bivalves (primarily Mytilus edulis galloprovincialis), barnacles, gastropods, crabs, chitons and amphipods were found in the diets of 2 or more species. Notolabrus celidotus was the only species observed to feed on salps and amphipods, while brachiopods and echinoderms (Terebratella sanguinea, Pentagonaster pulchellus and Evechinus chloroticus) were only found in the diet of Pseudolabrus miles. $N$. fucicola had a diet dominated by mussels ( $M$. edulis galloprovincialis) as indicated by the index of relative importance $(I R I=0.51)$. Niche space overlapped significantly $(\mathrm{p}<0.05)$ among all 3 species at nearly all outer fiord sites (Table 9). P. miles and N. fucicola had the lowest niche overlap, lacking significant values at both Thompson and Dusky Sounds but still achieved moderate overlap $\left(C_{\mathrm{MH}}>0.3\right)$. Diet overlap was very low between inner and outer fjord habitats for $N$. celidotus.

\section{Trophic position}

There was a significant difference among species (pseudo- $F_{2,117}=63.631, \mathrm{p}<0.001$ ) as well as among fjords (pseudo- $F_{2,117}=18.813, \mathrm{p}<0.001$ ) for individual trophic level and composition of basal organic matter sources (Table 10, Fig. 4). Pair-wise tests indicated that Pseudolabrus miles was significantly higher in 
Table 6. Corrected Akaike's information criterion $\left(\mathrm{AIC}_{\mathrm{c}}\right.$ ) rank values for 3 wrasse species from biological distance-based linear models (DistLM) as fitted to wrasse abundance for each species. For all species $\mathrm{n}=31$ survey sites. Only those models with cumulative total of Akaike's weights $>95 \%$ are presented. See Table 3 for habitat type parameters. K: kelp Ecklonia radiata; SU: sea urchins Evechinus chloroticus; BA: barnacles; BR: brachiopods; MU: mussels; K: no. of model parameters; $\Delta_{i}$ : change in $\mathrm{AIC}_{\mathrm{c} i} w_{i}: \mathrm{AIC}_{\mathrm{c}}$ weight

\begin{tabular}{|c|c|c|c|c|c|c|c|}
\hline Species & Model & $\begin{array}{c}\text { Log } \\
\text { likelihood }\end{array}$ & $K$ & $\mathrm{AIC}_{\mathrm{C}}$ & $\Delta_{i}$ & $w_{i}$ & $r^{2}$ \\
\hline \multirow[t]{7}{*}{ Notolabrus fucicola } & $\mathrm{K}+\mathrm{SU}$ & 2.179 & 4 & -29.740 & 0.000 & 0.451 & 0.662 \\
\hline & $\mathrm{K}+\mathrm{SU}+\mathrm{BA}$ & 2.157 & 5 & -27.716 & 2.024 & 0.164 & 0.670 \\
\hline & $\mathrm{K}+\mathrm{SU}+\mathrm{BR}$ & 2.173 & 5 & -27.237 & 2.503 & 0.129 & 0.664 \\
\hline & $\mathrm{K}+\mathrm{SU}+\mathrm{MU}$ & 2.179 & 5 & -27.066 & 2.674 & 0.118 & 0.662 \\
\hline & $\mathrm{K}+\mathrm{SU}+\mathrm{BR}+\mathrm{BA}$ & 2.141 & 6 & -25.294 & 4.446 & 0.049 & 0.675 \\
\hline & $\mathrm{K}+\mathrm{SU}+\mathrm{BA}+\mathrm{MU}$ & 2.157 & 6 & -24.818 & 4.922 & 0.038 & 0.670 \\
\hline & $\mathrm{K}+\mathrm{SU}+\mathrm{BR}+\mathrm{MU}$ & 2.173 & 6 & -24.340 & 5.400 & 0.030 & 0.664 \\
\hline \multirow[t]{10}{*}{ Pseudolabrus miles } & $\mathrm{K}+\mathrm{SU}$ & 4.037 & 4 & 25.994 & 0.000 & 0.254 & 0.553 \\
\hline & $\mathrm{K}+\mathrm{SU}+\mathrm{BR}$ & 3.954 & 5 & 26.169 & 0.175 & 0.232 & 0.589 \\
\hline & $\mathrm{K}+\mathrm{SU}+\mathrm{MU}$ & 4.002 & 5 & 27.630 & 1.636 & 0.112 & 0.568 \\
\hline & $\mathrm{K}+\mathrm{SU}+\mathrm{BR}+\mathrm{MU}$ & 3.917 & 6 & 27.980 & 1.986 & 0.094 & 0.603 \\
\hline & $\mathrm{K}+\mathrm{SU}+\mathrm{BA}$ & 4.035 & 5 & 28.619 & 2.625 & 0.068 & 0.554 \\
\hline & $\mathrm{K}+\mathrm{BR}$ & 4.128 & 4 & 28.729 & 2.735 & 0.065 & 0.510 \\
\hline & $\mathrm{K}+\mathrm{SU}+\mathrm{BR}+\mathrm{BA}$ & 3.951 & 6 & 29.008 & 3.014 & 0.056 & 0.589 \\
\hline & $\mathrm{K}$ & 4.230 & 3 & 29.313 & 3.319 & 0.048 & 0.457 \\
\hline & $\mathrm{K}+\mathrm{BR}+\mathrm{MU}$ & 4.072 & 5 & 29.737 & 3.743 & 0.039 & 0.537 \\
\hline & $\mathrm{K}+\mathrm{MU}$ & 4.175 & 4 & 30.141 & 4.147 & 0.032 & 0.486 \\
\hline \multirow[t]{10}{*}{ Notolabrus celidotus } & $\mathrm{K}+\mathrm{MU}$ & 4.322 & 4 & 34.558 & 0.000 & 0.298 & 0.373 \\
\hline & $\mathrm{K}+\mathrm{BA}+\mathrm{MU}$ & 4.272 & 5 & 35.721 & 1.163 & 0.167 & 0.404 \\
\hline & $\mathrm{K}+\mathrm{BR}+\mathrm{MU}$ & 4.288 & 5 & 36.193 & 1.635 & 0.132 & 0.394 \\
\hline & $\mathrm{K}$ & 4.489 & 3 & 37.066 & 2.508 & 0.085 & 0.260 \\
\hline & $\mathrm{K}+\mathrm{SU}+\mathrm{MU}$ & 4.317 & 5 & 37.083 & 2.525 & 0.084 & 0.376 \\
\hline & $\mathrm{K}+\mathrm{BA}$ & 4.430 & 4 & 37.800 & 3.242 & 0.059 & 0.302 \\
\hline & $\mathrm{K}+\mathrm{BR}+\mathrm{BA}+\mathrm{MU}$ & 4.253 & 6 & 38.055 & 3.497 & 0.052 & 0.415 \\
\hline & $\mathrm{K}+\mathrm{SU}+\mathrm{BA}+\mathrm{MU}$ & 4.255 & 6 & 38.107 & 3.549 & 0.051 & 0.414 \\
\hline & $\mathrm{K}+\mathrm{BR}$ & 4.454 & 4 & 38.521 & 3.963 & 0.041 & 0.285 \\
\hline & $\mathrm{K}+\mathrm{SU}+\mathrm{BR}+\mathrm{MU}$ & 4.285 & 6 & 39.024 & 4.466 & 0.032 & 0.396 \\
\hline
\end{tabular}

Table 7. Summed weights for biological predictor variables describing abundance of 3 wrasse species based on the sum of Akaike's information criterion weights $\left(w_{i}\right)$ for each model containing that factor. The highest weighted variables after kelp in bold

\begin{tabular}{|lccc|}
\hline Factor & $\begin{array}{c}\text { Notolabrus } \\
\text { fucicola }\end{array}$ & $\begin{array}{c}\text { Pseudolabrus } \\
\text { miles }\end{array}$ & $\begin{array}{c}\text { Notolabrus } \\
\text { celidotus }\end{array}$ \\
\hline Kelp & 1.0000 & 1.0000 & 1.0000 \\
Sea urchins & $\mathbf{0 . 7 4 3 9}$ & $\mathbf{0 . 8 1 6 2}$ & 0.1668 \\
Brachiopods & 0.2183 & 0.4861 & 0.2565 \\
Barnacles & 0.2229 & 0.1244 & 0.3280 \\
Mussels & 0.1998 & 0.2768 & $\mathbf{0 . 8 1 4 9}$ \\
\hline
\end{tabular}

trophic level and percent of organic matter originating from macroalgae than Notolabrus fucicola and $N$. celidotus (Table 10). A positive trend existed between increasing trophic level and increasing prey types originating from macroalgal sources in fish diet for $N$. celidotus $\left(r^{2}=0.497\right)$ and $N$. fucicola $\left(r^{2}=0.397\right)$. 'Fjord' was a significant factor for each species in describing variability in trophic level and composition of basal organic matter. Trophic level was significantly $(p<0.05)$ higher in Dusky Sound than Doubtful or Thompson Sound and significantly $(p<0.05)$ lower in Doubtful Sound (Table 10).

There were significant differences in dispersion (or niche breadth) of individual trophic position for each species among fjords $\left(F_{1,115}=14.144, \mathrm{p}<0.001\right)$ and among species $\left(F_{1,115}=6.5548, \mathrm{p}<0.05\right)$. Pair-wise tests indicated that Notolabrus celidotus had a significantly $(\mathrm{p}<0.05)$ greater dispersion of values than $P$. miles or $N$. fucicola (Table 10). Wrasses collected from Dusky Sound had a smaller dispersion of values than those collected from Doubtful and Thompson Sounds. 
Table 8. Revised index of relative importance (IRI) for basic prey categories of 3 wrasse species. Top 5 prey items for each species are in bold

\begin{tabular}{|lccc|}
\hline Prey type & $\begin{array}{c}\text { Notolabrus } \\
\text { fucicola }\end{array}$ & $\begin{array}{c}\text { Pseudolabrus } \\
\text { miles }\end{array}$ & $\begin{array}{c}\text { Notolabrus } \\
\text { celidotus }\end{array}$ \\
\hline Asteroidea (Pentagonaster pulchellus) & 0.0000 & 0.0014 & 0.0000 \\
Bryozoa & 0.0000 & 0.0038 & 0.0000 \\
Brachiopoda & 0.0000 & $\mathbf{0 . 0 4 6 7}$ & 0.0000 \\
Cnidaria (hydroid) & 0.0000 & 0.0003 & 0.0001 \\
Crustacea (hermit crab) & $\mathbf{0 . 0 0 1 7}$ & 0.0058 & 0.0000 \\
Crustacea (amphipoda) & 0.0000 & 0.0000 & $\mathbf{0 . 0 0 1 1}$ \\
Crustacea (cirripedia) & $\mathbf{0 . 0 0 7 0}$ & 0.0000 & $\mathbf{0 . 0 0 3 2}$ \\
Crustacea (unidentified crab) & $\mathbf{0 . 0 1 3 9}$ & 0.0001 & 0.0003 \\
Echinoidea (Evechinus chloroticus) & 0.0000 & 0.0092 & 0.0000 \\
Mollusca (bivalvia) & 0.0000 & $\mathbf{0 . 1 8 7 0}$ & $\mathbf{0 . 0 0 1 4}$ \\
Mollusca (gastropoda) & 0.0000 & 0.0004 & 0.0005 \\
Mollusca (mussels) & $\mathbf{0 . 5 0 7 4}$ & $\mathbf{0 . 0 9 0 3}$ & $\mathbf{0 . 3 6 2 8}$ \\
Mollusca (polyplacophora) & $\mathbf{0 . 0 0 5 1}$ & $\mathbf{0 . 0 0 9 5}$ & 0.0000 \\
Polychaeta & 0.0000 & $\mathbf{0 . 0 4 6 1}$ & 0.0002 \\
Macroalgae & 0.0003 & 0.0000 & 0.0000 \\
Teleostei (unidentified fish) & 0.0001 & 0.0000 & 0.0000 \\
Terrestrial insects & 0.0005 & 0.0000 & 0.0000 \\
Thaliacea (salp) & 0.0000 & 0.0000 & $\mathbf{0 . 0 0 1 5}$ \\
\hline
\end{tabular}

\section{DISCUSSION}

The results of the present study demonstrate the generalist nature of Notolabrus celidotus in comparison to Pseudolabrus miles and N. fucicola, which occupy comparatively narrow realized niche space in the Fiordland marine ecosystem. N. celidotus, though generally observed in abundance on coastal shallow rocky reefs throughout New Zealand (Schiel \& Hickford 2001), is also able to exploit semi-estuarine inner fjord habitats and a relatively broad prey field, while $P$. miles and $N$. fucicola are abundant only in highly productive mid and outer fjord habitats where they exploit a smaller range of resources. Modeling using an information theoretic approach provided a framework for understanding physical niche space by identifying site specific biological and physical gradients that best statistically describe wrasse distribution within Fiordland. $\delta^{13} \mathrm{C}, \delta^{15} \mathrm{~N}$ and diet used as indicators of variability in trophic position provided a useful proxy for biological niche by identifying individual variability in trophic level and composition of basal organic matter. This analysis indicated that individual variability in trophic position, as reflected by dispersion of trophic levels, may strongly influence niche breadth in this guild. Preliminary observations of dentary structure suggest wrasse morphology may also reflect differences in dietary niche.

Physical models suggested Notolabrus celidotus is best associated with the inner fjord environment, where wave height and salinity are at their minimum, though it exists in relative abundance along the length of the fjord (Wing et al. 2004). N. fucicola and Pseudolabrus miles on the other hand, are more abundant in outer fjord, high salinity, waveexposed environments. Low salinity towards the head of the fjord may limit the abundance of $N$. fucicola and $P$. miles as a result of decreasing prey availability (McLeod \& Wing 2008) as well as the physical stressors of a low salinity environment (Serafy et al. 1997). Wave exposure drives nutrient mixing, which is integral for the 
Table 10. Pair-wise permutational multivariate analysis of variance (PERMANOVA) and permutational analysis of multivariate dispersions (PERMDISP) test results indicating differences in trophic position as they relate to percentage macroalgae carbon source in the diet between (A) 3 wrasse species and (B) 3 fjord sites. Significant differences $(p<0.05)$ are in bold

\begin{tabular}{|lrrrrrr|}
\hline Species/site & \multicolumn{3}{c}{ PERMANOVA } & \multicolumn{3}{c|}{ PERMDISP } \\
& $\mathrm{df}$ & $t$ & $\mathrm{p}$ & $\mathrm{df}$ & $t$ & $\mathrm{p}$ \\
\hline (A) Species & & & & & & \\
Notolabrus fucicola, N. celidotus & 1,80 & 1.4238 & 0.1534 & 2,115 & 3.1092 & $\mathbf{0 . 0 1 1 0}$ \\
N. fucicola, Pseudolabrus miles & 1,40 & 4.3993 & $\mathbf{0 . 0 0 0 1}$ & 2,115 & 0.3181 & 0.7768 \\
P. miles, N. celidotus & 1,80 & 5.4373 & $\mathbf{0 . 0 0 0 1}$ & 2,115 & 2.5199 & $\mathbf{0 . 0 4 0 2}$ \\
(B) Site & & & & & & \\
Doubtful, Dusky & 1,64 & 12.5910 & $\mathbf{0 . 0 0 0 1}$ & 2,115 & 5.4647 & $\mathbf{0 . 0 0 0 1}$ \\
Doubtful, Thompson & 1,57 & 4.8255 & $\mathbf{0 . 0 0 0 1}$ & 2,115 & 1.4110 & 0.1642 \\
Dusky, Thompson & 1,79 & 6.6708 & $\mathbf{0 . 0 0 0 1}$ & 2,115 & 4.2065 & $\mathbf{0 . 0 0 0 1}$ \\
\hline
\end{tabular}

growth of sheltering macroalgal habitat (Hepburn et al. 2007) and primary production in general. Though N. celidotus are often associated with kelp forest habitat in coastal areas (Jones 1984a), this species also forages successfully in semi-estuarine inner fjord environments (McLeod et al. 2010).

Ranking of biological models demonstrated differences in statistical indicators of abundance among species. Abundances of Pseudolabrus miles and Notolabrus fucicola were best described by kelp Ecklonia radiata and sea urchin abundance, which may indicate the importance of sea urchins as a prey source or alternatively
A

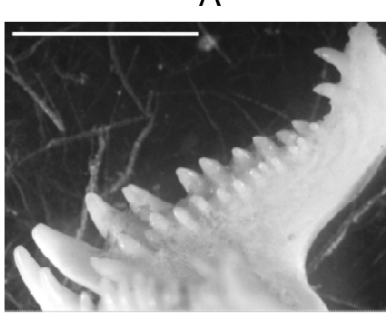

C

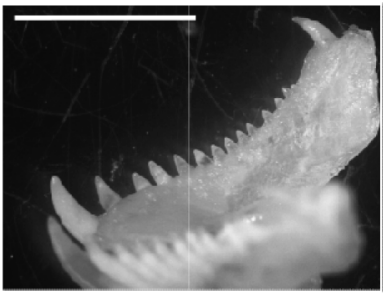

E



B

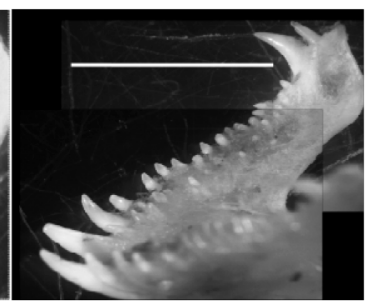

D

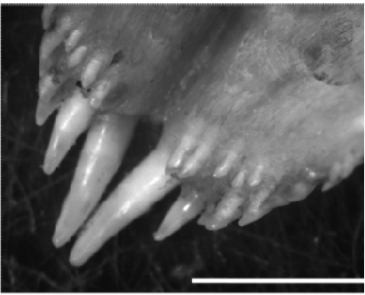

$\mathrm{F}$

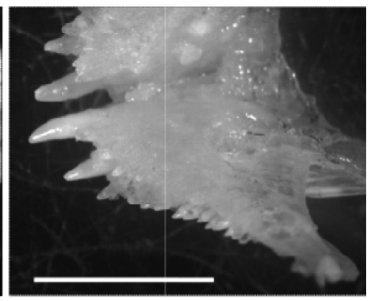

Fig. 5. Notolabrus fucicola, Notolabrus celidotus and Pseudolabrus miles. Dentary structure from 3 species of New Zealand wrasse. $(A, B, C)$ Upper jaw and dentary structure for (A) Notolabrus fucicola, (B) Pseudolabrus miles and (C) N. celidotus. (D,E,F) Lower jaw and dentary struc-

ture of (D) N. fucicola, (E) P. miles and (F) N. celidotus. Scale bars $=1 \mathrm{~cm}$
Fig. 4. Notolabrus fucicola, Notolabrus celidotus and Pseudolabrus miles. Individual trophic level values against percentage macroalgae in the diet for each wrasse species as indicated by the iso-source mass balance model 
that they live most successfully in highly productive, speciose, macroalgal reef environments where these organisms are found (Choat \& Ayling 1987). The correlation of $P$. miles with abundance of kelp and brachiopods may explain their high abundance in both mid and outer fjord habitats where brachiopods thrive in sheltered areas and caves below $10 \mathrm{~m}$ (Doherty 1979). The poor explanatory power of models for abundance of $N$. celidotus indicate that abundance of this species is less tightly coupled with biological factors that vary along the axis of each fjord and that their distribution and abundance are more strongly linked to the physical variables previously discussed.

The importance of kelp Ecklonia radiata abundance as a primary biological descriptor of wrasse abundance for all species emphasizes the influence of macroalgal habitat as a covariate of resource availability for reef fish communities. Wrasses depend on E. radiata for shelter during recruitment and adulthood (Pérez-Matus \& Shima 2010) and prey on algal grazers (e.g. Evechinus chloroticus) and benthic suspension feeders (e.g. Mytilus edulis galloprovincialis). The increase in trophic level with increasing macroalgal content in isotopic analysis of diet for Notolabrus celidotus and $N$. fucicola supports this observation. Within New Zealand, labrids have been found to live most successfully in algal stands where high densities of prey including small crustaceans and invertebrates take shelter in the understory (Choat \& Ayling 1987).

Analysis of trophic position using stable isotopes and diet supported conclusions drawn from physical and biological models, highlighting the generalist nature of Notolabrus celidotus in comparison to Pseudolabrus miles and N. fucicola. Though niche overlap was found to be high among all species in the outer fjord environment based on gut contents, spotties were found to feed on different items between inner and outer fjord environments (Table 9). N. celidotus shared similar trophic levels with $N$. fucicola; however, their smaller overall morphology suggests that they may partition shared prey such as bivalves by size class. The range of prey, from salps and small crustaceans (amphipods and isopods) to small size classes of bivalves (e.g. Mytilus edulis galloprovincialis) and gastropods found in the diet of $N$. celidotus support the significantly higher dispersion of trophic levels for this species relative to $N$. fucicola and $P$. miles. Previous studies confirm that N. celidotus also feeds on chemoautotrophic prey sources in inner Doubtful Sound (McLeod et al. 2010). The dietary plasticity of $N$. celidotus helps to explain its ability to exist in high abundance along the length of the fjord axis.

Pseudolabrus miles occupied a higher overall trophic level than Notolabrus celidotus or N. fucicola by exploiting a higher trophic level prey, including predatory invertebrates. Observations of diet supported this result by showing that $P$. miles exploits both benthic grazers such as sea stars Pentagonaster pulchellus and crustaceans in addition to lower trophic level suspension feeders (Mytilus edulis galloprovincialis and brachiopods) and algal grazers Evechinus chloroticus (Table 8).

Qualitative observations of dentary structure support differences observed in trophic plasticity. The sharp posterior teeth of Pseudolabrus miles and Notolabrus fucicola may be more specialized to prey on large bodied bivalves unlike $N$. celidotus, which exploits a wide range of prey including soft bodied benthic, epifaunal and planktonic organisms.

Significant differences in trophic level and composition of basal organic matter for each species among fjords may reflect differences in local hydrography, environmental gradients, or, in the case of Doubtful Sound, the influence of anthropogenic input of freshwater (McLeod \& Wing 2008). A smaller dispersion of high trophic levels and high percentage macroalgae content in the diet in Dusky Sound likely reflects a more complex food web associated with kelp forest habitat. For example, fish inhabiting rich macroalgal communities have been observed to more often share multiple high trophic level prey in comparison with those in barren boulder habitats where prey is less available (Angel \& Ojeda 2001).

Stable isotope analysis is dependent on several assumptions, namely that signatures of basal carbon sources must be stable over time to ensure a steady baseline from which to measure fractionation (Bearhop et al. 2004). Because carbon baselines for SPOM and macroalgae were collected in years prior to wrasse sampling in this study, basal source values could have affected conclusions on source pool use and trophic level by creating unrealistic baseline values. However, isotopic results appear to be reliable as they are consistent with observations of gut contents analysis.

The results presented here advance knowledge of the trophic ecology of New Zealand wrasses by providing the first description of niche partitioning among Notolabrus fucicola, N. celidotus and Pseudolabrus miles. The strong environmental gradients observed along the axes of multiple fjords provided an ideal study system for linking patterns in abundance in these species with physical and biological 
descriptors of habitat. Further, analysis of individual variability in trophic position provided a robust metric for quantitative comparisons of niche breadth among species in this guild. The advantage of this approach is that each species can be directly compared in terms of 2 quantitative metrics of food web structure, trophic level and composition of organic matter sources, and individual variability can be considered in terms of dispersion of these metrics. The resulting analyses of niche space better our understanding of factors influencing the abundance and distribution of wrasses at the regional scale in Fiordland. Wrasses likely exert important influences on community structure and patterns in biodiversity as abundant high trophic level consumers in Fiordland's subtidal marine ecosystem.

Acknowledgements. We thank those who have helped with this research project: L. Jack, N. Beer, D. Ham, P. Meredith, B. Dickson, P. Heseltine, the crew of the RV 'Southern Winds' (Department of Conservation), and Isotrace NZ Ltd.

\section{LITERATURE CITED}

Anderson MJ (2001) A new method for non-parametric multivariate analysis of variance. Austral Ecol 26:32-46

Anderson MJ, Gorley RN, Clarke KR (2008) PERMANOVA + for PRIMER: guide to software and statistical methods. PRIMER-E, Plymouth

Anderson TW (1994) Role of macroalgal structure in the distribution and abundance of a temperate reef fish. Mar Ecol Prog Ser 113:279-290

Angel A, Ojeda FP (2001) Structure and trophic organization of subtidal fish assemblages on the northern Chilean coast: the effect of habitat complexity. Mar Ecol Prog Ser 217:81-91

> Azzurro E, Fanelli E, Mostarda E, Catra M, Andaloro F (2007) Resource partitioning among early colonizing Siganus luridus and native herbivorous fish in the Mediterranean: an integrated study based on gut-content analysis and stable isotope signatures. J Mar Biol Assoc UK 87:991-998

Bearhop S, Adams CE, Waldron S, Fuller RA, MacLeod H (2004) Determining trophic niche width: a novel approach using stable isotope analysis. J Anim Ecol 73: 1007-1012

Bolnick DI, Svanbäck R, Fordyce JA, Yang LH, Davis JM, Hulsey CD, Forister ML (2003) The ecology of individuals: incidence and implications of individual specialization. Am Nat 161:1-28

Burnham KP, Anderson DR (1998) Model selection and inference: a practical information-theoretic approach, 1st edn. Springer-Verlag, New York, NY

$>$ Choat JH, Ayling AM (1987) The relationship between habitat structure and fish faunas on New Zealand reefs. J Exp Mar Biol Ecol 110:257-284

Choat JH, Schiel DR (1982) Patterns of distribution and abundance of large brown algae and invertebrate herbivores in subtidal regions of northern New Zealand. J Exp
Mar Biol Ecol 60:129-162

> Denny CM (2005) Distribution and abundance of labrids in northeastern New Zealand: the relationship between depth, exposure and pectoral fin aspect ratio. Environ Biol Fishes 72:33-43

Denny CM, Schiel DR (2001) Feeding ecology of the banded wrasse Notolabrus fucicola (Labridae) in southern New Zealand: prey items, seasonal differences, and ontogenetic variation. NZ J Mar Freshw Res 35:925-933

> Denny CM, Schiel DR (2002) Reproductive biology and population structure of the banded wrasse, Notolabrus fucicola (Labridae) around Kaikoura, New Zealand. NZ J Mar Freshw Res 36:555-563

> Doherty PJ (1979) A demographic study of a subtidal population of the New Zealand articulate brachiopod Terebratella inconspicua. Mar Biol 52:331-342

Francis M (1988) Coastal fishes of New Zealand: a diver's identification guide, 1st edn. Heinernam Reed, London

Fry B, Mumford PL, Tam F, Fox DD, Warren GL, Havens KE, Steinman AD (1999) Trophic position and individual feeding histories of fish from Lake Okeechobee, Florida. Can J Fish Aquat Sci 56:590-600

> Fulton CJ, Bellwood DR (2005) Wave-induced water motion and the functional implications for coral reef fish assemblages. Limnol Oceanogr 50:255-264

Hajisamae S, Chou LM, Ibrahim S (2004) Feeding habits and trophic relationships of fishes utilizing an impacted coastal habitat, Singapore. Hydrobiologia 520:61-71

- Hepburn CD, Holborow JD, Wing SR, Frew RD, Hurd CL (2007) Exposure to waves enhances the growth rate and nitrogen status of the giant kelp Macrocystis pyrifera. Mar Ecol Prog Ser 339:99-108

Horn HS (1966) Measurement of "overlap" in comparative ecological studies. Am Nat 100:419-424

Hutchinson GE (1957) Concluding remarks. Population studies: animal ecology and demography. Cold Spring Harb Symp Quant Biol 22:415-427

> Jones GP (1980) Growth and reproduction in the protogynous hermaphrodite Pseudolabrus celidotus (Pisces: Labridae) in New Zealand. Copeia 660-675

> Jones GP (1984a) The influence of habitat and behavioural interactions on the local distribution of the wrasse, Pseudolabrus celidotus. Environ Biol Fishes 10:43-57

Jones GP (1984b) Population ecology of the temperate reef fish Pseudolabrus celidotus Bloch \& Schneider (Pisces: Labridae). II. Factors influencing adult density. J Exp Mar Biol Ecol 75:277-303

- McArdle BH, Anderson MJ (2001) Fitting multivariate models to community data: a comment on distance-based redundancy analysis. Ecology 82:290-297

> McCutchan JH, Lewis WM, Kendall C, McGrath CC (2003) Variation in trophic shift for stable isotope ratios of carbon, nitrogen, and sulfur. Oikos 102:378-390

McFarland WN (1986) Light in the sea-correlations with behaviors of fishes and invertebrates. Integr Comp Biol 26:389-401

McLeod RJ (2007) The roles of key species and functional guilds in facilitating fluxes of organic matter across habitat boundaries in Fiordland. PhD thesis, University of Otago, Dunedin

> McLeod RJ, Wing SR (2007) Hagfish in the New Zealand fjords are supported by chemoautotrophy of forest carbon. Ecology 88:809-816

McLeod RJ, Wing SR (2008) Influence of an altered salinity regime on the population structure of two infaunal 
bivalve species. Estuar Coast Shelf Sci 78:529-540

McLeod RJ, Wing SR, Davis JP (2010) Habitat conversion and species loss alters the composition of carbon sources to benthic communities. Mar Ecol Prog Ser 411:127-136

Newsome SD, Martínez del Rio C, Bearhop S, Phillips DL (2007) A niche for isotopic ecology. Front Ecol Environ 5: 429-436

Pérez-Matus A, Shima JS (2010) Disentangling the effects of macroalgae on the abundance of temperate reef fishes. J Exp Mar Biol Ecol 388:1-10

Phillips DL, Gregg JW (2001) Uncertainty in source partitioning using stable isotopes. Oecologia 127:171-179

Pinkas L, Oliphant MS, Iverson IKL (1971) Food habits of albacore, bluefin tuna and bonito in California waters. Fish Bull Calif Dep Fish Game 152:1-105

Pinnegar JK, Polunin NVC (2000) Contributions of stableisotope data to elucidating food webs of Mediterranean rocky littoral fishes. Oecologia 122:399-409

Polovina JJ (1996) Decadal variation in the trans-Pacific migration of northern bluefin tuna (Thunnus thynnus) coherent with climate-induced change in prey abundance. Fish Oceanogr 5:114-119

Rilov G, Schiel DR (2006) Trophic linkages across seascapes: subtidal predators limit effective mussel recruitment in rocky intertidal communities. Mar Ecol Prog Ser 327: 83-93

Roberts CD, Stewart AL, Paulin CD, Neale D (2005) Regional diversity and biogeography of coastal fishes on the West Coast South Island of New Zealand. Science for Conservation, Vol. 250. New Zealand Department of Conservation, Wellington

Russell BC (1983) The food and feeding habits of rocky reef fish of north-eastern New Zealand. NZ J Mar Freshw Res 17:121-145

Rutger SM, Wing SR (2006) Effects of freshwater input on shallow-water infaunal communities in Doubtful Sound, New Zealand. Mar Ecol Prog Ser 314:35-47

Schiel DR, Hickford MJH (2001) Biological structure of nearshore rocky subtidal habitats in southern New Zealand. Science for Conservation, Vol. 182. New Zealand Department of Conservation, Wellington

Editorial responsibility: Janet Ley, St. Petersburg, Florida, USA
Serafy JE, Lindeman KC, Hopkins TE, Ault JS (1997) Effects of freshwater canal discharge on fish assemblages in a subtropical bay: field and laboratory observations. Mar Ecol Prog Ser 160:161-172

Tokeshi M (1999) Species coexistence: ecological and evolutionary perspectives. Blackwell Science, Oxford

> Wellenreuther M, Syms C, Clements KD (2008) Consistent spatial patterns across biogeographic gradients in temperate reef fishes. Ecography 31:84-94

Wing SR (2006) Biological monitoring of the Fiordland marine area and Fiordland's marine reserves - 2006. New Zealand Department of Conservation, Te Anau

Wing SR, Jack L (2010) Biological monitoring of the Fiordland (Te Moana of Atawhenua) marine area and Fiordland's marine reserves - 2010. New Zealand Department of Conservation, Dunedin

> Wing SR, Leichter JJ (2011) Variation in environmental conditions in a subtidal prey refuge: effects of salinity stress, food availability and predation on mussels in a fjord system. Mar Ecol Prog Ser 422:201-210

Wing SR, Gibbs MT, Lamare MD (2003) Reproductive sources and sinks within a sea urchin, Evechinus chloroticus, population of a New Zealand fjord. Mar Ecol Prog Ser 248:109-123

Wing SR, Bowman M, Smith F, Rutger S (2004) Analysis of biodiversity patterns and management decision making processes to support stewardship of marine resources and biodiversity in Fiordland - a case study. Report 2 of 3. Ministry for the Environment, Wellington

> Wing SR, Leichter JJ, Perrin C, Rutger SM, Bowman MH, Cornelisen CD (2007) Topographic shading and wave exposure influence morphology and ecophysiology of Ecklonia radiata (C. Agardh 1817) in Fiordland, New Zealand. Limnol Oceanogr 52:1853-1864

Wing SR, McLeod RJ, Clark KL, Frew RD (2008) Plasticity in the diet of two echinoderm species across an ecotone: microbial recycling of forest litter and bottom-up forcing of population structure. Mar Ecol Prog Ser 360:115-123

Witman JD, Grange KR (1998) Links between rain, salinity, and predation in a rocky subtidal community. Ecology 79:2429-2447

Submitted: April 29, 2011; Accepted: October 14, 2011 Proofs received from author(s): January 23, 2012 